\title{
Pakistan and the Quadrilateral Security Dialogue: Current and Future Perceptions
}

\section{Benjamin Clarke*}

\begin{abstract}
The Quadrilateral Security Dialogue (Quad or QSD), a proposed multilateral platform consisting of the United States (US), India, Japan and Australia intended to underpin a future Asia-Pacific order, has the potential to significantly impact Pakistan's international standing. As an important regional actor, Pakistan's responses to such a platform will be influential. This article discusses possible ways Pakistan is likely to perceive the Quad and its consequences. It analyses the nature of the Quad, Pakistan's foreign policy and current geopolitical trends to provide a framework for discussion. It then outlines two potential forms the Quad may take, aggressive and cooperative, and explores Pakistan's likely perceptions and responses. It finds that in case of an aggressive Quad, Pakistan will resist pressure and seek external support which may trigger greater strategic competition, whereas it may be willing to adopt a balanced foreign policy in the case of a cooperative Quad. These findings demonstrate the importance of considering such long-term implications at a time when other concerns are driving international engagement with Pakistan.
\end{abstract}

Keywords: Multilateralism, Foreign Policy, International Security, AsiaPacific, Quadrilateral Security Dialogue, Pakistan-US relations.

\footnotetext{
* The author is a research student at the Australian National University with a focus on conflict resolution and international security in the Asia-Pacific. He can be reached at: bclarke1@gmail.com.
}

@2019 by the Islamabad Policy Research Institute.

IPRI Journal —XIX (1): 30-55.

https://doi.org/10.31945/iprij.190102 


\section{Introduction}

\section{$\mathrm{T}$} he Western Pacific has been regarded as a site of strategic competition for some time, but the Indian Ocean Region (IOR) has recently begun to emerge as another pivotal area in major power rivalry. Driven by China's Two-Ocean Strategy, India's regional ambitions, economic competition and United States' (US) efforts to maintain ascendancy, the IOR has transformed from a geopolitical sideshow to a critical region with an uncertain future. ${ }^{1}$ In an effort to maintain order and protect their interests, the US, India, Japan and Australia are considering forming a partnership to exert influence across the Asia-Pacific. Known as the Quadrilateral Security Dialogue (Quad or QSD), this proposed multilateral platform is yet to solidify into a tangible force. However, it has the potential to substantially influence the region's future by becoming a mechanism for coordinated strategies and incident responses. As a country with strong interests in the IOR, Pakistan is keenly watching such developments. With a strategically important location, nuclear weapons, ongoing territorial disputes with India and significant relations with both China and the US, Pakistan is playing an important role in the region's shifting politics and will likely have a major impact on its future. It is, therefore, vital to consider the impact the Quad may have on Pakistan's interests.

This study will analyse how Pakistan perceives the Quad at present, and how it will likely perceive different forms it may take in the future. It will also explore what this means for regional stability. It will begin by analysing the Quad, its objectives and prospects in order to provide context for the following sections. It will, then, look at which domestic interest groups influence Pakistan's foreign policy and what their concerns are in the IOR in order to provide a background for analysing the country's security and strategic concerns about the Quad. The final

1 Anit Mukherjee, "Indian Ocean Region Strategic Outlook," in ASEAN and the Indian Ocean: The Key Maritime Links, eds. Sam Bateman, Rajni Gamage and Jane Chan (Singapore: S. Rajaratnam School of International Studies, 2017), 21-22, https://www.rsis.edu.sg/wp-content/uploads/2017/08/Monograph33.pdf. 


\section{Benjamin Clarke}

section will outline different forms the platform may adopt in the future, ranging from an aggressive entity to one based on international cooperation, and discuss how Pakistan will perceive and respond to them. This will demonstrate markedly different potential outcomes for Pakistan and the wider region, highlighting the importance of the country's perceptions and the ramifications of different policy options currently under consideration by governments in the US, India, Japan and Australia.

\section{The Quad}

The Quad is a proposed grouping of the Asia-Pacific's most prominent democracies, the US, India, Japan and Australia. The four countries first worked together in response to the 2004 Indian Ocean tsunami, but it took subsequent geopolitical pressures to raise the prospect of permanent cooperation. Warm relations between former US President George Bush and former Indian Prime Minister Manmohan Singh, who shared concerns about China's rise, drove talks. As a result, government representatives from each country met alongside the 2007 Association of Southeast Asian Nations (ASEAN) Regional Forum to discuss solidifying their ties. Despite a positive start, with a large multilateral naval exercise being held that year, this first attempt at building the Quad quickly evaporated after China protested, and new leadership in Japan and Australia moved in other directions. ${ }^{2}$ Discussions were eventually revived a decade later, and senior officials from the four countries met alongside the ASEAN Summit in November 2017. A second meeting followed in Singapore in June 2018 and the members agreed to consider holding regular meetings. ${ }^{3}$

This second push for the Quad was spurred by a growing wariness of China's intentions in the Asia-Pacific. Many things had changed after the first round of Quad talks fell apart post-2007, which happened when there was greater optimism that China would be content with a peaceful

2 Dhruva Jaishankar, "It's Time to Resuscitate the Asia-Pacific Quad," The Order from Chaos Blog, January 9, 2017, https://www.brookings.edu/blog/order-from-chaos/2017/ 01/09/its-time-to-resuscitate-the-asia-pacific-Quad.

3 Ankit Panda, "US, Japan, India, and Australia hold Senior Official-Level Quadrilateral Meeting in Singapore," Diplomat, June 8, 2018, https://thediplomat.com/2018/06/usjapan-india-and-australia-hold-senior-official-level-quadrilateral-meeting-in-singapore. 
economic rise and not flex its muscles internationally. The current geopolitical climate is much more adversarial. China's assertiveness in the South China Sea, its Air Defense Identification Zone (ADIZ) declaration in the East China Sea, and an expanded naval doctrine have raised the prospect of conflict. The inroads it has made into the IOR through military bases, economic influence, debt-trap diplomacy and port leasing has exacerbated concerns. ${ }^{4}$ The US 2017 National Security Strategy characterised this as 'a geopolitical competition between free and repressive visions of world order' and pledged to increase Quadrilateral cooperation with Japan, Australia and India in response. ${ }^{5}$ Shinzo Abe's return to power in Japan gave the talks additional momentum as he made restricting China's regional influence a priority due to disputes in the East China Sea. ${ }^{6}$ Troubled relations with China, including a 2017 border standoff, also helped spark India's renewed interest in the Quad. Prime Minister Modi's 'Act East' policy, which makes relations in East Asia a foreign policy priority, has also played a role. Meanwhile, Australia comprehensively committed itself to a US-led regional order by declaring it essential for the country's security and prosperity. ${ }^{7}$

While details of the Quad's purpose are scant at this point, all members frame it as a commitment to a 'free and open Indo-Pacific.' According to post-consultation statements of member countries this

${ }^{4}$ Jesse Barker Gale and Andrew Shearer, "The Quadrilateral Security Dialogue and the Maritime Silk Road Initiative" (brief, Center for Strategic and International Studies, Washington, D. C., 2018), https://csis-prod.s3.amazonaws.com/s3fs-public/publication/ 180717_GaleShearer_QuadSecurityDialogue.pdf?csNA9Z0fB6r4L9KKdBnc.a0LzXdN Tr7b.

5 White House, GoUS, National Security Strategy of the United States of America (Government of the United States, 2017), 45-46, https://www.whitehouse.gov/wpcontent/uploads/2017/12/NSS-Final-12-18-2017-0905.pdf.

6 Emma Chanlett-Avery, "Japan, the Indo-Pacific, and the 'Quad'” (brief, Chicago Council on Global Affairs, Chicago, 2018), https://www.thechicagocouncil.org/sites/default/files/brief-japan-and-thequad_chanlettavery_20180214.pdf.

7 Department of Defence, GoA, "2016 Defence White Paper" (paper, Department of Defence, Government of Australia, Canberra, 2016), 41-46, http://www.defence.gov.au/WhitePaper/Docs/2016-Defence-White-Paper.pdf.

${ }^{8}$ Gale and Shearer, "The Quadrilateral Security Dialogue and the Maritime Silk Road Initiative." 


\section{Benjamin Clarke}

includes a rules-based order, freedom of navigation and overflight, respect for international law, enhanced connectivity (referring to alternatives to China's Belt and Road Initiative [BRI]), maritime security, nuclear nonproliferation, and counterterrorism. However, the statements of different countries vary - India, for example, omits mention of freedom of navigation, respect for international law and maritime security (all were included by the other three members), while Japan omitted 'connectivity'. ${ }^{9}$ This reflects different threat perceptions and approaches to managing relations with China, as well as concerns about how upholding such principles may impact other matters. Despite this, all members agree that previously disparate regions in the Indian Ocean and Western Pacific are being bound more tightly by economic and security linkages, and this necessitates a new approach. They also recognise that each of the Quad members has similar values and interests, and that by cooperating they will have a stronger effect than various bilateral and trilateral arrangements. ${ }^{10}$

With goals of the Quad still fluid, how they will be achieved is even more unclear. There appears to be no interest in a military alliance at present, despite predictions that even the traditionally non-aligned India could be receptive to the idea if its fear of China deepens. ${ }^{11}$ Lower level military cooperation is frequently mentioned as an important aspect of the arrangement. The re-inclusion of Australia to the trilateral Malabar naval exercises between Japan, India and the US is often used as an indicator of the Quad's progress, with India's decision to again exclude Australia in

${ }^{9}$ Ministry of External Affairs, Government of India, "India-Australia-Japan-U.S.

Consultations on Indo-Pacific," press release, November 12, 2017, http://mea.gov.in/press-releases.htm?dtl/29110/IndiaAustraliaJapanUS_Consultations_ on_IndoPacific_November_12_2017; and Ankit Panda, "US, Japan, India, and Australia hold Working-Level Quadrilateral Meeting on Regional Cooperation," Diplomat, November 13, 2017, https://thediplomat.com/2017/11/us-japan-india-and-australia-holdworking-level-quadrilateral-meeting-on-regional-cooperation.

${ }^{10}$ Richard Rossow and Sarah Watson, "China Creates a Second Chance for the "Quad"" (Washington, D.C.: Asia Maritime Transparency Initiative, 2016), https://amti.csis.org/4379-2/.

${ }^{11}$ Jeff M. Smith, Yuki Tatsumi, Rajeswari Pillai Rajagopalan, Rory Medcalf and David Brewster "Return of the Quad", Diplomat, issue 42, May 2018, https://magazine.thediplomat.com/\#/issues/-LAWCg2zSGAbYVn-2Qr2/preview/LAWCnijekQqONjhfT7t. 
2018 interpreted as a setback. ${ }^{12}$ India's lack of trust in Australia is a significant obstacle to military cooperation. Tensions following the former's nuclear tests and Australia's former opposition to export uranium to India generated lingering hostilities in New Delhi's security establishment that also doubts Canberra's international influence.

However, Shinzo Abe believes the Quad may pursue its goals even without military activities, citing coordinated diplomatic pressure, advocacy for international law and targetted economic investment as potential aspects of a comprehensive effort to solidify a regional order. ${ }^{13}$ A US economic strategy aimed at 'advancing a free and open IndoPacific' reveals likely approaches, even though the amount committed is much less than the sum of China's regional investments. ${ }^{14}$ Australia and Japan have joined the US in pursuing the multifaceted strategy that aims to drive growth and develop infrastructure. ${ }^{15}$

One thing is certain: for the Quad to achieve its purpose, India must increase its influence and take on a more active role in the IOR for the platform to be effective. Its importance is emphasised by each country despite its relatively minor capacity for power projection and regional influence at present. ${ }^{16}$

\footnotetext{
${ }^{12}$ Emanuele Scimia, "Malabar 2018: India Deals a Blow to Australia and 'the Quad'," Southasian Monitor, May 2, 2018, http://southasianmonitor.com/2018/05/02/malabar2018-india-deals-a-blow-to-australia-and-the-quad/.

${ }^{13}$ Shinzo Abe, interview, Financial Review, January 20, 2018, https://www.afr.com/afrspecial/shinzo-abe-interview-with-the-australian-financial-review-20180118-h0kpj5.

${ }^{14}$ US Department of State, Government of the United States, "Advancing a Free and Open Indo-Pacific," press release, July 30, 2018, https://www.state.gov/r/pa/prs/ps/2018/07/284829.htm.

${ }^{15}$ Overseas Private Investment Corporation, "US-Japan-Australia Announce Trilateral Partnership for Indo-Pacific Infrastructure Investment,” press release, July 30, 2018, https://www.opic.gov/press-releases/2018/us-japan-australia-announce-trilateralpartnership-indo-pacific-infrastructure-investment.

16 Robert Stewart-Ingersoll and Derrick Frazier, "India as a Regional Power: Identifying the Impact of Roles and Foreign Policy Orientation on the South Asian Security Order," Asian Security 6, no. 1 (2010): 51-73 (70), DOI: 10.1080/14799850903472003.
} 


\section{Benjamin Clarke}

The US acknowledges India's 'leadership role in Indian Ocean security,' while Australia is aware of New Delhi's importance to the future balance of power. ${ }^{17}$ The country is also 'extremely important' to Japan which labels it a latent economic power with common security interests. ${ }^{18}$ As for India itself, it also envisions a much more expansive role. Many in the country see the Indian Ocean as naturally falling under their area of influence and key to India's 'manifest destiny' to become a great power. ${ }^{19}$ The latter's maritime strategy is beginning to reflect such ambitions. In 2015, it was expanded to include provision of security to a vast area of the Indian Ocean, including its major choke points, and playing a supporting role well into the Pacific (Figure 1) which is a significant escalation since $2007 .^{20}$

${ }^{17}$ White House, GoUS, National Security Strategy of the United States of America, 50; and Department of Defence, GoA, "2017 Foreign Policy White Paper" (paper, Department of Defence, Government of Australia, Canberra, 2017), 25, https://www.fpwhitepaper.gov.au/foreign-policy-white-paper.

18 Ministry of Defense, GoJ, Defense of Japan 2017 (Government of Japan, 2017), 367.

19 David Brewster, You Ji, Zhu Li, Pramit Pal Chaudhuri, Abhijit Singh, Rajan Menon, Darshana M. Baruah, John W. Garver, and Rory Medcalf, "India and China at Sea: A Contest of Status and Legitimacy in the Indian Ocean," Roundtable in Asia Policy 22 (2016): 5-6.

20 Gurpreet S. Khurana, "India's Maritime Strategy: Context and Subtext," Maritime Affairs: Journal of the National Maritime Foundation of India 13, no. 1 (2017): 14-26 (15-16), https://doi.org/10.1080/09733159.2017.1309747. 
Figure-1

Indian Navy's Areas of Interest

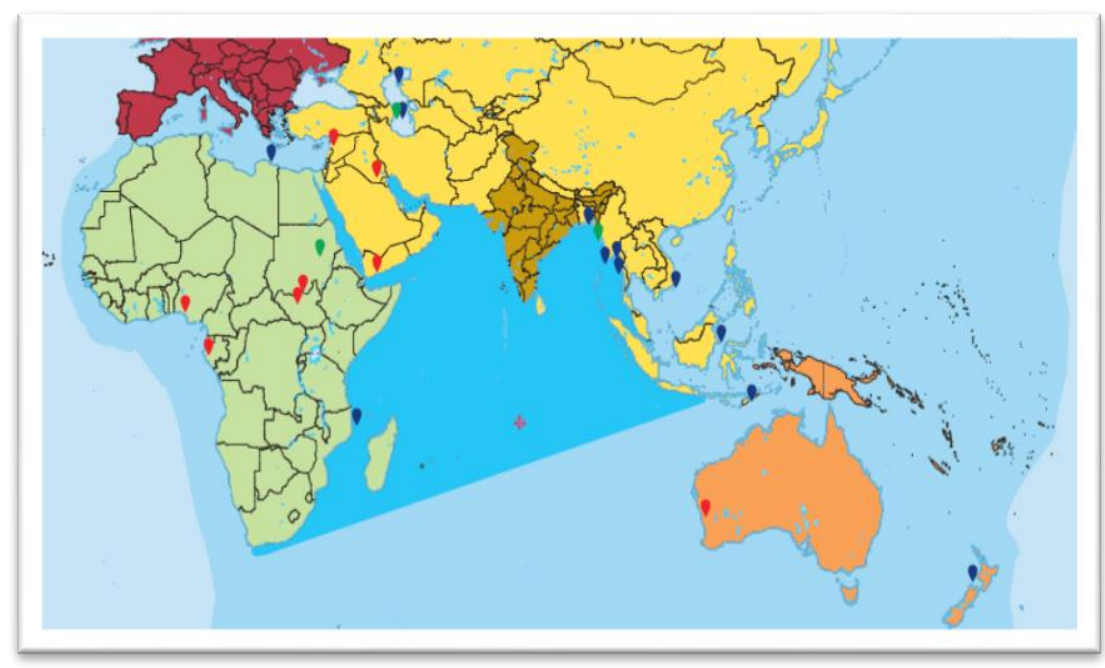

Source: Integrated Headquarters, Ministry of Defence (Navy), GoI, Ensuring Secure Seas: Indian Maritime Security Strategy (Government of India, 2015), 36.

Note: Dark Blue-primary areas of interest; Light Blue-secondary areas of interest.

Given how far the Quad is from becoming a meaningful force, it is understandable that some may disregard it. There are many obstacles to overcome. Not the least of which is India's policy of neutrality ever since independence. There are also doubts in member countries about the reliability of others, and leadership changes could easily derail the process. Moreover, there is considerable work to be done in narrowing down the Quad's objectives from broad statements. A rules-based order is easy to agree on, but much more difficult to define in detail - particularly when India is dissatisfied with many aspects of the status quo that the 


\section{Benjamin Clarke}

other members seek to uphold. ${ }^{21}$ However, the underlying trends that have pulled the four countries together are continuing and their interests are converging. It is possible that a gradual building of concerns, or a strategic shock (such as China establishing a military base in Pakistan), ${ }^{22}$ will provide the necessary impetus to overcome the obstacles and make it a reality.

\section{Pakistan's Interests in IOR}

It is often difficult to define Pakistan's national interests in detail. While most countries regularly publish white papers or similar documents to articulate their concerns and objectives, the last time Pakistan did so was in $1976 .{ }^{23}$ Its foreign policy is characterised by a lack of consensus on key issues and a disorganised process which often produces $a d$ hoc policies. ${ }^{24}$ This is due to poor governance and weak institutions which means formal processes of policy formulation are often disregarded. Instead, interest groups can exert undue influence over government policy, producing a perpetual power struggle over government policy. ${ }^{25}$ This lack of a unified vision must be considered when analysing the country's interests and approaches to the region. Rather than solely relying on government statements, it is also necessary to examine the interests of Pakistan's military, which often has contrasting views and considerable power over

${ }^{21}$ Alexander Davis, “Australia and India: Different Worlds,” Interpreter, July 17, 2018 , https://www.lowyinstitute.org/the-interpreter/australia-and-india-different-worlds.

${ }^{22}$ Department of Defense, GoUS, Annual Report to Congress: Military and Security Developments Involving the People's Republic of China 2018, report (Government of United States, 2018), 112, https://media.defense.gov/2018/Aug/16/2001955282/-1/1/1/2018-CHINA-MILITARY-POWER-REPORT.PDF.

${ }^{23}$ Ministry of Law, Justice and Parliamentary Affairs, GoP, Abbottabad Commission Report on the Killing of Osama Bin Laden, report (Government of Pakistan, 2013), 322.

24 Ayaz Ahmed, "Foreign Policy Implications for Pakistan," Defence Journal 21, no. 3 (2017): 69; and Arshad Zaman, "Sovereign Development: Toward a Grand Strategy for Pakistan," Pakistan Development Review 56, no. 4 (2017): 14.

${ }^{25}$ Javid Hussain, "Process of Foreign Policy Formulation in Pakistan," in Short Course on the Foreign Policy Process in Pakistan (Lahore: Pakistan Institute of Legislative Development and Transparency, 2004), 56-57, http://www.millat.com/wp-content/ uploads/ pdf/democracy/1/fp_proceedings_04_2004.pdf. 
foreign policy. ${ }^{26}$ Public opinion is also a particularly powerful force in Pakistan, where deeply entrenched beliefs are capable of fuelling unrest which can reverse policy and threaten governments. ${ }^{27}$

One constant among politicians, the military and the general population is that reservations about India loom large in their regional calculations. ${ }^{28}$ Their common concerns have created a consensus which produces a firm set of national interests. A turbulent recent history has created an institutional and cultural mistrust of New Delhi which is unlikely to change in the foreseeable future. Pakistan's economic and military power relative to India is, thus, a major concern given its smaller size, as is diplomatic prestige. A more powerful India is interpreted as an existential threat, so attempting to achieve a balance has been a driver of key decisions in the past including international alignments and the production of nuclear weapons..$^{29}$ To prevent this gap from widening, Pakistan opposes any elevation of India's regional and international standing - the legitimisation of the latter as a nuclear country by the US is cause for concern, as is any momentum for greater Indian influence in the United Nations (UN). ${ }^{30}$ There are widespread fears that India seeks regional hegemony, and an internationally accepted role as the predominant power in South Asia (that has some basis ${ }^{31}$ ), which may have

${ }^{26}$ Vali Nasr, The Dispensable Nation: American Foreign Policy in Retreat (New York: Anchor Books, 2013), 69; and Shaheen A. Gillani, "Process of Foreign Policy Formulation in Pakistan," in Short Course on the Foreign Policy Process in Pakistan (Lahore: Pakistan Institute of Legislative Development and Transparency, 2004), 58-59, http://www.millat.com/wp-content/uploads/pdf/democracy/1/ fp_proceedings_04_2004.pdf.

${ }^{27}$ Paul Staniland, "America and Pakistan after 2014: Toward Strategic Breathing Space," in Pakistan's Enduring Challenges, eds. C. Christine Fair and Sarah J. Watson (Philadelphia: University of Pennsylvania Press, 2015), 220-221.

${ }^{28}$ Karamatullah K. Ghori. "Sixty Years of Pakistan's Foreign Policy," Pakistan Horizon 60 no. 2 (2007): 9-24.

${ }^{29}$ Ibid.

${ }^{30}$ Cyril Almeida, “Analysis: A Nuclear Deal - Need or Prestige?” Dawn, October 21, 2015, https://www.dawn.com/news/1214525.

${ }^{31}$ Sunil Khilnani, Rajiv Kumar, Pratap Bhanu Mehta, Prakash Menon, Nandan Nilekani, Srinath Raghavan, Shyam Saran and Siddharth Varadarajan, Nonalignment 2.0: A Foreign and Strategic Policy for India in the Twenty First Century, report (New Delhi: 


\section{Benjamin Clarke}

severe consequences for Pakistan's security and autonomy. ${ }^{32}$

Pakistan's strategic concerns extend to the Indian Ocean, particularly as India's Blue Water Navy grows with a more expansive doctrine. With 95 per cent of Pakistan's trade being seaborne, its economy depends on secure Sea Lines of Communication (SLOCs) ${ }^{33}$ Pakistan has limited capacity to ensure their security or to keep chokepoints free from interference, meaning the predominant naval power in the region can achieve considerable influence over it. The security of its ports is another important consideration in case of naval conflict. Until recently, Karachi was its only naval base, and that was easily blockaded during the 1971 war due to its proximity to India. The development of Gwadar Port near the Iranian border gives Pakistan strategic depth as well as an important position on the SLOCs leading out of the Persian Gulf. ${ }^{34}$ However, this advantage could be negated by a navy capable of long-distance operations. Yet another concern is the likely nuclearisation of the ocean as India prepares submarines capable of nuclear strikes. Pakistan's strategists fear this will undermine the country's nuclear deterrence and cause strategic imbalance. ${ }^{35}$

Despite the consensus that India poses a threat to Pakistan, opinions on how to deal with that vary. The predominant voice in such matters traditionally comes from the military, which has generally favoured a confrontational approach and transactional international partnerships (such as providing the US with logistical support in return for financial

National Defence College, 2012), 15-17,

https://www.kcl.ac.uk/sspp/departments/kii/documents/NonAlignment20.pdf.

32 "Pakistan Not to Tolerate India's 'Hegemony' in Region: Sartaj Aziz," Nation, January

16, 2017, https://nation.com.pk/16-Jan-2017/pakistan-not-to-tolerate-india-s-hegemonyin-region-sartaj-aziz.

${ }^{33}$ Hasan Yaser Malik, "Strategic Importance of Gwadar Port," Journal of Political Studies 19, no. 2 (2012): 57-69 (57), http://pu.edu.pk/images/journal/pols/pdf-files/gwadar $\% 20$ article -winter2012.pdf.

${ }^{34}$ Inayat Kalim, "Gwadar Port: Serving Strategic Interests of Pakistan,” South Asian Studies: A Research Journal of South Asian Studies 31, no. 1 (2016): 207-221, http://pu.edu.pk/images/journal/csas/PDF/14\%20Inayat\%20Kaleem_v31_no1_janjun2016.pdf.

${ }^{35}$ Ghazala Yasmin Jalil, "India's Development of Sea-Based Nuclear Capabilities: Implications for Pakistan,” Strategic Studies 38, no. 1 (2018): 34-47 (41-45), http://issi.org.pk/wp-content/uploads/2018/04/3-SS_Ghazala_Yasmeen_Jalil_No1_2018.pdf. 
assistance) to bolster its strength. The military's strategic culture is influenced by a need to resist India and a perception that politicians cannot be trusted with national security. ${ }^{36}$ However, there is also evidence of a growing perception that a different approach should be taken. In a purposive sampling survey of 50 military officers, defence experts and civil bureaucrats, 16 of which were senior officers ranked at or above the level of Colonel, 54 per cent of respondents indicated that the national security policy should prioritise internal security and regional trade and cooperation. Only 15 per cent favoured external security and domestic economic performance. The study found a growing perception that poverty is Pakistan's most serious problem. ${ }^{37}$

The potential for economic cooperation with India to improve Pakistan's situation is also gaining traction, aided by the possibility that control of India's economic activity may give Pakistan additional leverage. ${ }^{38}$ Opinions among politicians vary, but it is more common to find those who believe that improving relations and resolving disputes amicably is the best approach to minimising the threat from India. However, as well as contending with the military establishment they must also consider the public, large portions of which are staunchly anti-Indian and readily mobilised against leaders perceived as serving foreign

\footnotetext{
${ }^{36}$ C. Christine Fair, Pakistan's Strategic Culture: Implications for How Pakistan Perceives and Counters Threats, report no. 61 (Washington, D.C.: National Bureau of Asian Research, 2016), 3-4, https://www.nbr.org/wp-content/uploads/pdfs/publications/ special_report_61_pakistans_strategic_culture_december2016.pdf.

${ }^{37}$ Muhammad Azfar Anwar and Zain Rafique, "Defense Spending and National Security of Pakistan: A Policy Perspective," Democracy and Security 8, no. 4 (2012): 374-399 (394-396), https://doi.org/10.1080/17419166.2012.739551.

${ }^{38}$ Muhammad Afzal, "Indian Quest for Reconnecting to Central Asia via Land Route and its Implications for Pakistan," Opinion: A Journal of the Armed Forces War College 4 (2016): 55-74 (71-73), https://ndu.edu.pk/afwc/pub/Opinion-Vol-No.4.pdf; and Javed Ashraf Qazi, "How Security Considerations Influence Foreign Policy in Pakistan: The Role of Security Agencies and How This Practice Compares with Other Countries of the World," in Short Course on the Foreign Policy Process in Pakistan (Lahore: Pakistan Institute of Legislative Development and Transparency, 2004), 27-28, http://www.millat.com/wp-content/uploads/pdf/democracy/1/ fp_proceedings_04_2004.pdf.
} 


\section{Benjamin Clarke}

interests. ${ }^{39}$ Despite the prevalence of anti-Indian attitudes, 62 per cent of Pakistanis believe it is important to improve bilateral relations suggesting large support bases for both confrontational and conciliatory approaches. $^{40}$

The position of China in the IOR is also vital to Pakistan's interests. While most see Beijing as an important partner, just how deep this relationship should be is debateable. Underpinning China-Pakistan relations is the shared belief that India must not be permitted to dominate South Asia and the Indian Ocean. This gives China an enduring interest in a strong Pakistan to balance against India - a convenient situation for the former as this can provide economic and military assistance as well as a sympathetic permanent member of the United Nations Security Council (UNSC) ${ }^{41}$ From a military perspective, the prospect of a friendly China projecting its forces into the IOR is an attractive one as India's navy is rapidly outpacing Pakistan's. China's economic commitment through the China-Pakistan Economic Corridor (CPEC) gives Beijing a further interest in Pakistan's security. CPEC is an ambitious project to economically link western China to Pakistan's Gwadar Port, and includes many associated development and infrastructure projects. It has drawn the support of most political parties which desperately seek development and foreign investment. As a result, the public image of China is the most favourable out of any country in the world. ${ }^{42}$

\footnotetext{
${ }^{39}$ Najmuddin A. Shaikh, "How Security Considerations Influence the Formulation of Foreign Policy," in Short Course on the Foreign Policy Process in Pakistan (Lahore: Pakistan Institute of Legislative Development and Transparency, 2004), http://www.millat.com/wp-content/uploads/pdf/democracy/1/ fp_proceedings_04_2004.pdf.

${ }^{40}$ PRC, Pakistani Public Opinion Ever More Critical of U.S., report (Washington, D.C.: Pew Research Center, 2012), 20, http://www.pewresearch.org/wp-content/uploads/sites /2/2012/06/Pew-Global-Attitudes-Project-Pakistan-Report-FINAL-Wednesday-June-272012.pdf.

${ }^{41}$ Andrew Scobell, Ely Ratner and Michael Beckley, China's Strategy toward South and Central Asia: An Empty Fortress, report (Santa Monica: RAND Corporation, 2014), 6263, https://www.rand.org/content/dam/rand/pubs/research_reports/RR500/RR525/ RAND_RR525.pdf.

${ }^{42}$ PRC, "Opinion of China," Global Indicators Database (Washington, D.C.: Pew Research Center, 2015), http://www.pewglobal.org/database/indicator/24/survey/17/.
} 
The role of the US is more controversial. The military is the strongest supporter of partnership with Washington. The predominant view among officers is that the US cannot be completely trusted, but partnership with it brings important advantages. This results in the military hedging by offering only limited cooperation. ${ }^{43}$ This arrangement appears satisfactory, as a common theme in recent publications from military officers is that Pakistan can and should adopt a stance that balances good ties with both China and the US. ${ }^{44}$ Political parties have generally cooperated with the US on foreign and security policy yet maintain very critical attitudes for domestic audiences. They regularly condemn the US over drone strikes, the war in Afghanistan, criticism of Pakistan and events such as the bin Laden raid. ${ }^{45}$ This has contributed to widespread anti-American sentiment among the populace, where 62 per cent of people hold an unfavourable view of the US. ${ }^{46}$ Anti-Americanism is a major obstacle to improved bilateral relations and fuels opposition to a regional US role. However, neither country has made significant efforts to change such perceptions.

${ }^{43}$ Hussain Nadim, "Neither Friend nor Foe: Pakistan, the United States and the War in Afghanistan" (paper, Lowy Institute, Sydney, 2017), 4, https://www.lowyinstitute.org/sites/default/files/documents/Nadim\%20-\%20Pakistan $\% 2 \mathrm{C} \% 20$ the $\% 20$ United $\% 20$ States $\% 20$ and $\% 20$ the $\% 20$ war\%20in\%20Afghanistan_WE B.pdf.

${ }^{44}$ Qaisar Suleman, "US-India Strategic Alliance and Pakistan's Security Concerns," Opinion: A Journal of the Armed Forces War College 2, no. 2 (2014): 26-38 (35-36), http://www.academia.edu/37745887/Armed_Forces_War_College_Journal_2014; Imran, Kashif, Tauqeer, Moin and Zahani, "The New Silk Road and Maritime Silk Road - Impact on Economic and Security Environment," Opinion: A Journal of the Armed Forces War College 4 (2016): 1-12 (10-11), https://ndu.edu.pk/afwc/pub/Opinion-VolNo.4.pdf; and Irfan Shakeel, Yasir Nawaz, Majid, Tanvir Butt and Alhaji, "Indian Power Potential and Rising Asymmetry vis-à-vis Pakistan," Opinion: A Journal of the Armed Forces War College 4 (2016): 37-54 (53), https://ndu.edu.pk/afwc/pub/OpinionVol-No.4.pdf

${ }^{45}$ Karl Kaltenthaler and William J. Miller, "Partner or Enemy? The Source of Attitudes toward the United States in Pakistan," in Pakistan's Enduring Challenges, eds. C. Christine Fair and Sarah J. Watson (Philadelphia: University of Pennsylvania Press, 2015), 233.

${ }^{46}$ PRC, "Opinion of the United States," Global Indicators Database (Washington, D.C.: Pew Research Center, 2015), http://www.pewglobal.org/database/indicator/1/survey/17/response/Unfavorable/. 


\section{Current Perceptions about Quad in Pakistan}

There is relatively little discussion directly concerning the Quad as it remains a potential entity. However, there is much more discourse surrounding the geopolitical trends that led to the platform. This allows one to build a reasonably clear picture of how the Quad is perceived.

The Quad is a product of renewed emphasis on great power relations among its members, which includes a reduced focus on Pakistan as the 'War on Terror' loses centrality in geopolitics. It also involves India taking on a much greater regional role along with closer ties to the other member states, a fundamental change in IOR dynamics. These processes have now been underway for some time and attract considerable attention from influential decision makers and commentators in Pakistan. Their effects on the country's foreign policy are already discernible.

At present, the Quad is interpreted as a direct threat to Pakistan's interests. The widely held assumption that Pakistan should pursue parity with India in hard power and international influence is the basis of such concerns. Deepening US-India ties are often interpreted as an 'Indo-US nexus' intended to exert dominance over the IOR that will inevitably marginalise Pakistan. ${ }^{47}$ The government expressed such concerns through the Ministry of Foreign Affairs (MoFA), which claimed that the US is undermining strategic stability through policies of discrimination and exceptionalism. ${ }^{48}$ Military publications also conclude that closer US-India strategic cooperation is inevitable and will have negative implications for Pakistan's security by exacerbating the power differential and affording New Delhi a stronger say on international issues. ${ }^{49}$ This is a reasonable argument - as long as adversarial relations between India and Pakistan

\footnotetext{
${ }^{47}$ Ashfaq Ahmad Malik and Nazir Hussain, "Indo-US Nexus to Isolate Pakistan: Options and Responses," Journal of Political Studies 25, no. 1 (2018): 113-124 (113-116), http://pu.edu.pk/images/journal/pols/pdf-files/7_25_1_18.pdf; and Syed Shahid Hussain Bukhari, "Indo-US Strategic Partnership and Pakistan's Security: A Theoretical Evaluation,” Strategic Studies 35, no. 3 (2015): 71-86 (74), http://issi.org.pk/wpcontent/uploads/2016/05/Dr._Syed_Shahid_Vol.35_No.3_2015.pdf.

48 "Waiver to India by US to Further Erode Non-Proliferation Norms: Pakistan," Pakistan Today, August 2, 2018, https://www.pakistantoday.com.pk/2018/08/02/waiver-to-indiaby-us-to-further-erode-non-proliferation-norms-pakistan/.

${ }^{49}$ Suleman, "US-India Strategic Alliance and Pakistan's Security Concerns," 34-35.
} 
persist, the US' position will affect the balance of power. Public opinion reflects these concerns, with 50 per cent of Pakistanis believing US policy favours India, while only 9 per cent think Pakistan is advantaged. ${ }^{50}$

Despite the belief that Islamabad can maintain constructive relations with Washington even as it becomes closer with New Delhi, current US policies are eroding that viewpoint, and stoking fears that Pakistan may be framed as a threat in the future. ${ }^{51}$ Frustrated at Pakistan's perceived lack of action against terrorism, the US has become increasingly assertive in attempting to coerce its leaders. ${ }^{52}$ This is due to the dominance of the US military and intelligence agencies in influencing Washington's approach to Pakistan - which view the latter as an immediate security problem and undermine simultaneous attempts to build the broader-focused, positive relationship that policymakers in Islamabad crave. ${ }^{53}$ What was once the pillar of US-Pakistan relations, military cooperation, is severely strained. A recent suspension of security assistance has even cut much-vaunted educational programmes for Pakistani officers which may have a longterm impact on bilateral relations. ${ }^{54}$ Pakistan's official military publication describes current US policy as haphazard and confused; while the Army and MoFA both point out Pakistan feels betrayed. ${ }^{55}$

While considerable hope remains that the relationship can be repaired, there has been a noticeable shift in Pakistan's foreign relations as it seeks economic and security assurances. It has primarily turned to China as their mutual concerns about US-India ties drive closer cooperation,

\footnotetext{
${ }^{50}$ PRC, Pakistani Public Opinion Ever More Critical of U.S., 21.

${ }^{51}$ Nasr, The Dispensable Nation: American Foreign Policy in Retreat, 62-63.

52 Ibid.

53 Ibid.

${ }^{54}$ Idrees Ali and Phil Stewart, "Exclusive: As Trump Cracks Down on Pakistan, U.S. Cuts Military Training Programs," Reuters, August 10, 2018, https://www.reuters.com/article/us-pakistan-usa-military-exclusive/exclusive-as-trumpcracks-down-on-pakistan-u-s-cuts-military-training-programs-idUSKBN1KV166.

${ }^{55}$ Asna H. Rizvi, "The Changing U.S.-Pakistan Security Cooperation Scenario," Hilal English, June 2018, https://www.hilal.gov.pk/eng-article/the-changing-u.s.---pakistansecurity-cooperation-scenario/MjE0.html; and Kay Johnson, "Pakistan Army Chief Says Nation Felt 'Betrayed' by US Criticism," Reuters, January 12, 2018, https://www.reuters.com/article/us-pakistan-usa/pakistan-army-chief-says-nation-feltbetrayed-by-u-s-criticism-idUSKBN1F11AI.
} 


\section{Benjamin Clarke}

although engagement with Russia is also growing with calls for more political, strategic and economic cooperation to diversify options. ${ }^{56}$ Military reliance on China has grown as the US is no longer considered a reliable source of military equipment - the value of Chinese arms exports to Pakistan is now over 20 times that of the US and includes high-end systems like fighter jets and submarines. ${ }^{57}$ The Minister of Defence in 2011 requested that China build a naval base at Gwadar and military officers have recommended that a formal alliance be sought, demonstrating the utility they see in this. ${ }^{58}$ The election of Imran Khan as Prime Minister, who recently claimed Pakistan must delink from the US, may also prove significant. ${ }^{59}$ However, it is unlikely he will have the power to follow through on much of his anti-American rhetoric.

Pakistan's shift towards China has included enormous financial commitments which effectively put it within Beijing's sphere of influence. Limited export industries have given it little option other than reliance on CPEC to propel the future economy. The decision to participate in CPEC was motivated by the need to restore Pakistan's security and geopolitical standing, and resist economic pressure from Western institutions. ${ }^{60}$ The project is enormously popular in Pakistan where many hope it will bring socioeconomic prosperity. However, concerns also exist about

${ }^{56}$ Shabir Ahmed Khan, "Russia's Changing Policy towards South Asia: Options for Pakistan," in Regional Dynamics and Strategic Concerns in South Asia, ed. Sarah Siddiq Aneel (Islamabad: Islamabad Policy Research Institute, 2018) 163-164, http://www.ipripak.org/wp-content/uploads/2018/06/rdib1362018.pdf.

${ }^{57}$ Anwar Iqbal, "Pakistan Reducing Dependence on US Arms: FT Report," Dawn, April 19, 2018, https://www.dawn.com/news/1402479/pakistan-reducing-dependence-on-usarms-ft-report.

${ }^{58}$ Farhan Bokhari and Kathrin Hille, "Pakistan Turns to China for Naval Base," Financial Times, May 22, 2011, https://www.ft.com/content/3914bd36-8467-11e0-afcb00144feabdc0; and Imran Raza Naqvi and Wasim Hussain, "India's Balancing Act: Relations with the US, Russia and China," Opinion: A Journal of the Armed Forces War College 1, no. 2 (2013): 41-53, https://ndu.edu.pk/afwc/pub/OPINION-Vol.1-No.2Dec.pdf.

${ }^{59}$ Phil Stewart, "US Weighs Pakistani Blowback as it Piles Pressure on Islamabad," Reuters, January 6, 2018, https://www.reuters.com/article/us-usa-pakistan/u-s-weighspakistani-blowback-as-it-piles-pressure-on-islamabad-idUSKBN1EV02G.

${ }^{60}$ Zulfqar Khan, "Synergizing Foreign and Security Policy of Pakistan," Margalla Papers 21 (2017): 49-60 (55), https://www.ndu.edu.pk/issra/issra_pub/articles/margallapaper/Margalla-Paper-2017/4-Synergizing-Foreing-Dr-Zulfqar-Khan.pdf. 
Pakistan and the Quadrilateral Security Dialogue:

Current and Future Perceptions

consequences for the country's autonomy. ${ }^{61}$ Opaque conditions surrounding massive loans with high interest rates may be unsustainable for Pakistan's developing economy and represent a debt trap, giving China substantial leverage in the future. This may include control over vital infrastructure - Gwadar port being the primary concern. ${ }^{62}$

\section{Looking to the Future}

Having established Pakistan's interests as interpreted by the main parties influencing foreign policy and their current approach to the Quad, it is possible to discuss how they will perceive it after possible future developments. At this early stage, the Quad's objectives and methods are not clearly defined. There are many options available, but this section will outline two potential forms the Quad may take. To provide contrast, this will involve options on either end of the spectrum - aggressive and cooperative - but the future Quad may fall anywhere between these two options or employ different strategies at different times.

\section{A 'Hard' Quad}

In this scenario, the Quad takes on an aggressive pursuit of its interests in the IOR. While a formal military alliance seems unlikely, there is still scope for much more military and political cooperation that would make it the most powerful entity in the IOR, and enable it to engage in economic, diplomatic and military coercion. This may involve direct pressure on Pakistan to change its behaviour or attempts to contain it by nullifying its ability to have an impact on the IOR. Current US policies towards Pakistan, along with India's approach where there is little momentum for improving relations, does suggest some potential for this to become a reality. There are, of course, significant obstacles, such as Japan's

\footnotetext{
${ }^{61}$ Syed Fazl-e-Haider, "Pakistan and its Foreign Debt Obligation," Pakistan \& Gulf Economist, August 14, 2017, http://www.pakistaneconomist.com/2017/08/14/pakistanforeign-debt-obligation/; and Yigal Chazan, "Pakistan's Risky Reliance on China Set to Grow," Diplomat, March 26, 2018, https://thediplomat.com/2018/03/pakistans-riskyreliance-on-china-set-to-grow. 


\section{Benjamin Clarke}

constitutional constraints on using military force and Australia's aversion to risking its economic ties with China, but it is possible that these may be overcome with time and new developments.Pakistan's future perceptions of a 'hard' Quad are relatively straightforward. The current fears that it represents a threat to the country will become a concrete reality. In a scenario where the platform is committed to becoming the ascendant power in the IOR and pursuing that goal aggressively, Pakistan's pursuit of strategic balance with India will be opposed. This undermines the former's security and will be viewed with great concern by the military, politicians, civil society and the general populace alike. Current perceptions that India is an aggressive power determined to isolate Pakistan will be applied to the Quad as a whole, but with even more concern considering the greater hard power and international influence available to it. ${ }^{63}$ The arguments of those who seek peace with India and are open to negotiations on Indian Occupied Kashmir (IOK) would be greatly discredited, as a 'hard' Quad would convey the message that the only option for calm is to accept India as the regional leader - something very few in Pakistan would be open to.

A 'hard' Quad would face a major challenge in asserting its will over Pakistan. Recent history shows that Islamabad is unlikely to bend in the face of external pressure. ${ }^{64}$ The major exception to this was President Musharraf abandoning the Taliban and agreeing to aid US forces in the aftermath of $9 / 11$. However, it was only a unique set of circumstances that produced this. There was significant international and domestic US support for action in Afghanistan, and a refusal to assist from Pakistan would have had major consequences. The US also had significant leverage at the time, offering to end Pakistan's international isolation which Musharraf's coup had triggered and replace it with billions of dollars in assistance. ${ }^{65}$ The situation is now very different. The US has less credibility for military action in the region, and it now has very little leverage over Pakistan after again cutting aid and degrading prospects for a long-term strategic relationship. Pakistan is aware of this, and several

\footnotetext{
${ }^{63}$ Malik and Hussain, "Indo-US Nexus to Isolate Pakistan: Options and Responses," 114115.

${ }^{64}$ Nasr, The Dispensable Nation: American Foreign Policy in Retreat, 4.

${ }^{65}$ Ibid., 53-54.
} 
years of threats and bluffs from the US have not only failed to increase cooperation, but reduced it. ${ }^{66}$

There are multiple structural factors that will shield Pakistan from external coercion in the future. It is becoming less vulnerable to isolation as its strategic and economic links with China deepen. The country is now more reliant on China than the US - the threat of unilateral US sanctions carry less weight. ${ }^{67}$ Pakistan is also well placed to withstand any threat of military coercion. Pakistan's leadership has faith that the nuclear deterrent will prevent any direct attack, a belief which has been strengthened by recent incidents such as the 1999 Kargil War, 2001-02 standoff and 2016 Uri attacks. On each of these occasions, India was unwilling to significantly escalate the conflict despite having conventional superiority and domestic support to do so. ${ }^{68}$ Pakistan's strategic culture will also drive resistance to any coercion involving India. ${ }^{69}$

If the Quad is interpreted as a direct threat, it is likely that Pakistan will try to deepen its relations with China even further and exact stronger commitments. Islamabad has a long history of aligning with stronger powers to balance against threats, pragmatically switching allegiances depending on the political climate at the time. ${ }^{70}$ Such behaviour would be consistent with current trends of a shift towards reliance on China. At present, while China sees the importance of its relations with India in order to project an image of a peacefully rising power, ${ }^{71}$ Beijing is likely to see a 'hard' Quad as a threat, which would change its strategic calculus

\footnotetext{
${ }^{66}$ Ibid., 71.

${ }^{67}$ Shubhangi Pandey, "US Sanctions on Pakistan and Their Failure as a Strategic Deterrent" (brief no. 251, Observer Researcher Foundation, New Delhi, 2018), https://www.orfonline.org/research/42912-u-s-sanctions-on-pakistan-and-their-failureas-strategic-deterrent/.

${ }^{68}$ Sumit Ganguly and Michael R. Kraig, "The 2001-2002 Indo-Pakistani Crisis: Exposing the Limits of Coercive Diplomacy," Security Studies 14, no. 2 (2005): 290-324 (297306), https://doi.org/10.1080/09636410500232958.

${ }^{69}$ Fair, Pakistan's Strategic Culture: Implications for How Pakistan Perceives and Counters Threats, 3-4.

${ }^{70}$ Jabin T. Jacob, "China-Pakistan Relations: Reinterpreting the Nexus," China Report 46, no. 3 (2010): 217-299 (220), https://doi.org/10.1177/000944551104600304

${ }^{71}$ Scobell, Ratner and Beckley, China's Strategy toward South and Central Asia: An Empty Fortress, 62.
} 


\section{Benjamin Clarke}

and make it much more receptive to Pakistan's overtures regarding strategic commitments. CPEC's importance as an alternate supply route to Southeast Asia's choke points would become much more significant, and China has previously demonstrated a willingness to use its position on IOK as a bargaining chip in relations with India. ${ }^{72}$

Pakistan's likely perceptions and reactions to a 'hard' Quad may pose a danger to stability in the IOR. There is a real risk of two blocs with opposing interests forming, locked in a zero-sum game as they jostle for influence. This would be a major departure from the prevailing methods of maintaining peace in the IOR by balancing interests. For example, China generally avoids antagonising India and chastises Pakistan as required to maintain stability, and cooperates with the US on crisis management and peacebuilding. ${ }^{73}$ As alignments harden and willingness to compromise reduces, it will become more difficult to manage a complex region which is already a dangerous flashpoint. ${ }^{74}$ Such blocs would also be an obstacle to the IOR's economic integration, hindering development and reducing incentives for cooperation. Even on current trends, economic investment is fuelling strategic competition rather than hindering it, and is a key consideration for Quad members as they seek ways to counter China's growing influence. ${ }^{75}$

\section{A 'Soft' Quad}

It is possible for the Quad to adopt a much more careful approach by reducing its emphasis on direct competition and military activities. By pursuing their shared interests, while also being sensitive to the concerns of others and leaving scope for cooperation with them, the platform may be able to construct a more inclusive regional order within which it is a preeminent power. This would involve a less aggressive security

\footnotetext{
${ }_{72}^{72}$ Jacob, "China-Pakistan Relations: Reinterpreting the Nexus," 225-226.

${ }^{73}$ Andrew Small, "Accelerating Competition: The Risk of Regional Blocs in South Asia," in Regional Dynamics and Strategic Concerns in South Asia, ed. Sarah Siddiq Aneel (Islamabad: Islamabad Policy Research Institute, 2018), 122-123.

${ }^{74}$ Zulfiquar Ahmed Qureshi, "Global Strategic Threats to International Peace and Security Post Cold War Era," Opinion: A Journal of the Armed Forces War College 2, no. 2 (2014): 85-103 (93), https://ndu.edu.pk/afwc/pub/OPINION-Vol.2-No.2.pdf.

${ }^{75}$ Ibid., 124.
} 
framework with an emphasis on upholding norms every country can benefit from by ensuring freedom of movement, rule of law and security assistance to other states requiring it. India's vision for a polycentric political order in which the legitimate interests of numerous countries are accommodated may provide some inspiration for such an arrangement. ${ }^{76}$ Its emphasis on cooperation with ASEAN is a good basis for this. ${ }^{77}$

Singapore's Prime Minister sees merit in the Quad underpinning an inclusive regional architecture, which may also draw support from countries like Sri Lanka and Vietnam which are concerned about their future. ${ }^{78}$ Shinzo Abe's belief that military activities are not essential for the Quad to have influence supports experts in India and Australia who argue strategic deterrence should not be its goal, and military cooperation should only complement extensive diplomatic and foreign policy efforts. ${ }^{79}$ Australia's recent Asia-Pacific Economic Cooperation (APEC) meeting announcement on joint economic and infrastructure projects to strengthen Pacific nations indicates the type of work a 'soft' Quad could undertake. ${ }^{80}$ Given China's economic, political and strategic importance to the Quad members, there are substantial incentives to avoid excessively aggravating it by constructing an aggressive platform - particularly when a 'soft'

\footnotetext{
${ }^{76}$ Davis, "Australia and India: Different Worlds."

77 "PM Modi Participates in ASEAN-India Breakfast Summit in Singapore," Economic Times, November 15, 2018, https://economictimes.indiatimes.com/news/politics-andnation/pm-modi-participates-in-asean-india-breakfast-summit-in-singapore/articleshow/ 66629736.cms.

${ }^{78}$ Kenneth Cheng, "PM Lee Warns against Formation of Rival Regional Blocs, as Fresh Alignments Take Shape," Today Online, March 15, 2018,

https://www.todayonline.com/world/pm-lee-warns-against-formation-rival-regionalblocs-fresh-alignments-take-shape; and Barana Waidyatilake, "Sri Lanka's Strategy for Regional Security,” Diplomat, July 19, 2018, https://thediplomat.com/2018/07/srilankas-strategy-for-regional-security.

${ }^{79}$ Abe, interview; Gurmeet Kanwal, "Pakistan's Gwadar Port: A New Naval Base in China's String of Pearls in the Indo-Pacific" (brief, Center for Strategic \& International Studies, Washington, D.C., 2018), https://csis-prod.s3.amazonaws.com/s3fspublic/publication/180717_Kanwal_PakistansGwadarPort.pdf; and Ramesh Thakur, "Australia and the QUAD," Strategist, July 5, 2018, https://www.aspistrategist.org.au/australia-and-the-QUAD/.

80 "Australia Focuses on Pacific after APEC Meeting Ends in Disagreement," SBS News, November 19, 2018, https://www.sbs.com.au/news/australia-focuses-on-pacific-afterapec-meeting-ends-in-disagreement.
} 


\section{Benjamin Clarke}

framework may be even more effective in reducing China's influence by lowering regional threat perceptions.

In the case of a 'soft' Quad, Pakistan's perception is likely to be much less uniform. If Pakistan is constructively engaged by the Quad and there is less of an obvious threat, the fractured nature of its governing system will become more apparent as different interest groups and narratives compete for influence over foreign policy. Such a Quad will still be received poorly due to the enhanced international standing it will bring India. However, the tendency of military and bureaucratic elites to desire good relations with the US will likely prevent a strong reaction if they believe the possibility for such relations persist, even in the face of long-term strategic differences. ${ }^{81}$

Recent history demonstrates that maintaining good relations with Pakistan is possible even while building ties with India. ${ }^{82}$ China has been balancing its relations with India and Pakistan since 1979. Cooperation has steadily improved and China even adopted a neutral stance during the 1999 Kargil War. Despite this, good diplomacy and a continued commitment to Pakistan's development and security means that relations are stronger than ever. ${ }^{83}$ Pakistan's policymakers have also come to accept that the US desires good relations with India, and understand that this does not inherently mean US-Pakistan ties must suffer as a result. ${ }^{84}$ While India itself being part of the Quad will complicate matters, this does suggest that there is scope for the country's leadership to understand that a 'soft' Quad is not intended to target it, and develop foreign policy accordingly. This may include positive bilateral relations with other Quad members despite disapproving of their drift towards India.

\footnotetext{
${ }^{81}$ Michael Kugelman and Raoof Hasan, "What a Year of Track II Discussions Says about the Future of U.S.-Pakistan Relations," War on the Rocks, November 30, 2017, https://warontherocks.com/2017/11/year-track-ii-discussions-says-future-u-s-pakistanrelations/.

82 Jingdong Yuan, "Beijing's Balancing Act: Courting New Delhi, Reassuring Islamabad," Journal of International Affairs 64, no. 2 (2011): 37-54 (42-46).

${ }^{83}$ Ibid.

${ }^{84}$ Syed Farooq Hasnat, "Pakistan-US Relations on Slippery Grounds: An Account of Trust and its Deficit," Pakistan Vision 12, no. 1 (2011): 23-69 (52), http://pu.edu.pk/images/journal/studies/PDF-FILES/Artical-2-Vol-12-1-2011.pdf.
} 
A 'soft' Quad would also leave space for activities that could actively improve Pakistan's perceptions of its regional standing. While it may be difficult for the Quad itself to engage with it due to troubled IndiaPakistan relations, without coordinated confrontational policies member states would be able to cultivate their bilateral ties with Islamabad. A resumption of US cooperation with Pakistan would restore a vital component of their relationship, while expanded cooperation from Australia and Japan as they become more active in the IOR would build Islamabad's confidence. An eventual drawdown of international involvement in Afghanistan would facilitate this by reducing political spats over smaller-scale issues, and allowing broad strategic concerns to drive relations. ${ }^{85}$ This would also allow Quad members to improve their image among Pakistan's population, where drone strikes and other conflict-related incidents are major drivers of anti-Americanism and nationalistic sentiment. Efforts could be made to increase the visible impact of aid and investment, which has been less successful than Chinese projects in capturing the public's imagination. This may soften opinions and reduce the impetus for political parties to oppose the US (and the Quad's) interests. ${ }^{86}$

A 'soft' Quad which is not broadly perceived as a threat within Pakistan would likely produce a less volatile IOR. Even though it will still be viewed with suspicion by strategists who oppose a greater regional role and international influence for India, this is unlikely to override their enthusiasm for positive relations with the US and its partners. If the Quad manages to engage with Pakistan, and provide opportunities for it to benefit from the political order, or at least leave enough breathing space for its members to do so individually, it is unlikely that the country's leadership will be supportive of a confrontational approach. China will remain an influential partner, but the danger of opposing blocs forming would be reduced, and it is more likely that the historical pattern of maintaining regional stability by balancing interests would continue. The

\footnotetext{
${ }^{85}$ Staniland, "America and Pakistan after 2014: Toward Strategic Breathing Space,” 222224.

${ }^{86}$ Nasr, The Dispensable Nation: American Foreign Policy in Retreat, 61.
} 


\section{Benjamin Clarke}

potential for a 'soft' Quad to reduce hostility among the populace and soften politicians' stances would contribute to preventing an escalation of tensions. This could potentially serve as a catalyst for greater stability to develop over time, supported by the already significant popular support base for improved bilateral relations with India.

\section{Conclusion}

The Quad is a potentially transformative platform that may forge new international partnerships and permanently alter the dynamics of the AsiaPacific. As it is still in its formative stages, the Quad is undecided on how it will pursue its goal of a 'free and open' region which will safeguard its members' interests in a contested environment, with options including military, economic and diplomatic endeavours. In the IOR, this would represent a significant change as India coordinates its efforts with outside actors that support its role as a more influential regional power. This would be a major challenge for Pakistan, which has long sought strategic and international parity with India to defend itself from what it sees as a threatening power. Pakistan is already taking action in response to the geopolitical changes which the Quad is a part of, shifting its political orientation away from the US and becoming more reliant on China, which is seen as a more reliable partner due to mutual interests in limiting India's influence. This trend will continue if the Quad coalesces into an assertive regional force. Pakistan would likely resist pressure to accept India's regional supremacy, and instead, closely align itself with China in opposition to the Quad, raising the spectre of competing power blocs. Alternatively, if the platform models itself as a moderating force for an inclusive regional order which Pakistan can benefit from, it is more likely that the country will balance its interests, and maintain positive relations with both China and the Quad, creating greater potential for regional stability.

This holds clear implications for policymakers in Quad member countries, particularly in the US and India, where confrontational policies towards Pakistan are in favour to serve short- and medium-term interests relating to domestic politics and the war in Afghanistan. It is imperative that they weigh up the long-term consequences of such policies. Such 
Pakistan and the Quadrilateral Security Dialogue:

Current and Future Perceptions

considerations are also relevant to those in Australia and Japan who will decide the trajectory of the Quad, and must be fully aware of its implications. The future order of the IOR is as important to Pakistan as any other country - it is equally important that policymakers there understand the potential dangers facing the region, and consider how their own actions may influence the attitudes and policies of others. 